14 McCormack WM, Almeida PC, Bailey PE, Grady EM, Lee Y-H. Sexual activity and vaginal colonisation with genital mycoplasmas. $¥ A M A$ 1972; 221: 1375-7.

15 Hammerschlag MR, Doraiswamy B, Cox $\mathrm{P}$, Cummings $M$, McCormack WM. Colonisation of sexually abused children with genital mycoplasmas. Sex Transm Dis 1987; 14: 23-5.

16 Horowitz BJ, Edelstein SW, Lippman L. Sexual transmission of candida. Obstet Gynecol 1987; 69: 883-6.

17 Gardner J. Comparison of the vaginal flora in sexually Gardner JJ. Comparison of the vaginal flora in sexually
abused and non abused girls. $\mathcal{F}$ Pediatr 1992; 120: abused and non abused girls. $F$ Pediatr 1992; 120:

18 Ingram DL, White ST, Lyna PR, et al. Gardnerella vaginalis infection and sexual contact in female children. Child Abuse Negl 1992; 16: 847-53.

19 Paradise JE, Campos JM, Friedman HM, Frishmuth G. Vulvovaginitis in premenarcheal girls: clinical features and diagnostic evaluation. Pediatrics 1982; 70: 193-8.

20 Altchek A. Pediatric vulvovaginitis. $f$ Reprod Med 1984; 29: 359-75.

21 Sweet RL, Gibbs RS. Infectious vulvovaginitis. Infectious diseases of the female genital tract. 2nd Ed. Baltimore: Williams and Wilkins, 1990: 216-28.

22 Pierce AM, Hart CA. Vulvovaginitis: causes and management. Arch Dis Child 1992; 67: 509-12.

\title{
The importance of clonality - Langerhans' cell histiocytosis
}

In the latest edition of the leading British textbook of paediatrics it is stated that the group of diseases we all used to know as histiocytosis $\mathrm{X}$ 'are not malignancies but proliferations probably secondary to defects of immunoregulation'. Work in several centres in the United States (Cheryl L Willman and colleagues, New England fournal of Medicine 1994; 331: 154-60) now casts doubt on that thesis.

As you know, in females each somatic cell randomly inactivates either the maternal or the paternal $\mathrm{X}$ chromosome early in embryonic development (lyonisation). After that all progeny cells have the same $\mathrm{X}$ inactivation as their progenitor cell. Tissues derived by polyclonal expansion will therefore have mixed $\mathrm{X}$ inactivation but those derived monoclonally will contain cells all with the same inactivated $\mathrm{X}$ chromosome. Monoclonal proliferation is taken to be neoplasia.

These workers used X linked polymorphic DNA probes to examine tissues from 10 female patients aged 3 months to 25 years with Langerhans' cell histiocytosis ( $\mathrm{LCH})$. Three had acute disseminated LCH (Letterer-Siwe disease), four had the intermediate form (Hand-Schüller-Christian syndrome), and three had a single bony lesion (eosinophilic granuloma). The patterns of $\mathrm{X}$ chromosome inactivation in biopsy material were compared with those in blood. Using a probe for the $\mathrm{X}$ linked human androgen receptor gene proved informative in all 10 patients and clonal cells were demonstrated in the tissue lesions of nine. In one patient clonality could not be assessed because of constitutional asymmetrical lyonisation. The estimated proportion of clonal cells in the LCH lesions varied from 20 to $65 \%$. There was a high correlation between the percentage of clonal cells detected and the percentage of CD1a-positive histiocytes in a lesion suggesting that the two are the same.

These results indicate that all the clinical forms of $\mathrm{LCH}$ are clonal neoplastic disorders. The authors hypothesise that the different clinical forms may arise from different mutations in somatic cells and that, although the demonstration of clonality alone does not give any indication as regards prognosis, it might be possible in future to predict the likely clinical course by identifying the specific mutation. This then could be a guide to appropriate treatment. 